\title{
Plantarisin Asal Lactobacillus plantarum IIA-1A5 sebagai Pengawet Alami Daging Ayam Bagian Paha pada Suhu Refrigerator
}

\author{
Plantaricin from Lactobacillus plantarum IIA-1A5 for biopreservative in Chicken Drumstick During \\ Refrigerator Temperature
}

\author{
H. N. Siswara ${ }^{1}$, I. I. Arief ${ }^{2}, \&$ Z. Wulandari ${ }^{2}$ \\ ${ }^{1}$ Dinas Peternakan Kabupaten Bojonegoro \\ ${ }^{2}$ Departemen Ilmu Produksi dan Teknologi Peternakan, Fakultas Peternakan, IPB University \\ Jl. Agatis Kampus IPB Darmaga, Bogor, 16680 \\ Email koresponden author : irmaisnafia@gmail.com
}

\begin{abstract}
Naturally preservative has potential to appllied as food preservative. A biopreservative can used for food is bacteriocin. Bacteriocin is peptide compound produced by lactic acid bacteria and has antimicrobial activity. Lactobacillus plantarum is one of lactic acid bacteria produce bacteriocin called plantaricin. Plantaricin has antimicrobial activity against pathogen bacteria. Aplication of plantaricin will become an alternative for developing biotechnology in biopreservative. The aim of this research was to evaluate the effectiveness of plantaricin IIA-1 A5 as biopreservative to physical properties and microbiological chicken meat at refrigerator temperature. There were two methods used, purification of plantaricin and its aplication to chicken meat. This research used completely randomized design with factorial pattern, then Duncan Multiple Rank Test. The results showed that there was a significant $(\mathrm{P}<0.05)$ interaction of gived plantarisin with specific storage time $(0,2,4,6,8$, and 10 days $)$ in chicken meat on the quality of meat. As conclusion, plantaricin IIA-1 A5 effectively inhibited pathogenic bacteria so total microbe was lower than control. Plantaricin could be recommended as a biopreservative for chicken meat.
\end{abstract}

Keywords: biopreservative, chicken drumstick, plantaricin, purification

\begin{abstract}
ABSTRAK
Bahan pengawet alami menjadi bahan yang potensial untuk diaplikasikan dalam pengawetan bahan pangan. Bahan pengawet alami yang aman dan dapat digunakan untuk makanan yaitu bakteriosin. Bakteriosin adalah senyawa peptida yang diproduksi oleh bakteri asam laktat di dalam bahan pangan dan memiliki aktivitas antimikroba. Lactobacillus plantarum merupakan salah satu bakteri asam laktat penghasil bakteriosin yang disebut sebagai plantarisin. Plantarisin memiliki aktivitas antimikroba terhadap kelompok bakteri patogen. Aplikasi plantarisin akan menjadi alternatif untuk perkembangan dunia bioteknologi dalam bidang pengawetan makanan karena merupakan bahan pengawet alami. Penelitian bertujuan untuk mengevaluasi efektivitas plantarisin IIA-1A5 sebagai pengawet terhadap kualitas sifat fisik dan mikrobiologi daging ayam bagian paha selama penyimpanan suhu refrigerator. Metode yang digunakan terdiri dari 2 tahap yaitu purifikasi plantarisin serta aplikasi plantarisin IIA-1A5 10\% pada daging ayam bagian paha. Penelitian menggunakan rancangan acak lengkap pola faktorial, kemudian dilakukan uji lanjut Duncan Multiple Rank Test (DMRT). Hasil menunjukkan bahwa interaksi pemberian plantarisin $10 \%$ dengan lama penyimpanan daging ayam bagian paha berpengaruh nyata $(\mathrm{P}<0.05)$ terhadap kualitas daging. Kesimpulan, plantarisin IIA-1A5 efektif menghambat pertumbuhan bakteri sehingga nilai total mikroba lebih rendah dibanding kontrol. Plantarisin dapat direkomendasikan sebagai pengawet alami pada daging.
\end{abstract}

Kata kunci: paha ayam, pengawet alami, plantarisin, purifikasi 


\section{PENDAHULUAN}

Dewasa ini, bahan pengawet alami atau biasa disebut biopreservatif menjadi bahan yang potensial untuk diaplikasikan dalam pengawetan atau mempertahankan kualitas bahan pangan (Ammor et al.2006). Bahan pengawet alami yang aman dan dapat digunakan untuk makanan yaitu bakteriosin. Bakteriosin dapat digunakan sebagai agen biopreservatif karena mampu mencegah pembusukan pangan dengan menghambat pertumbuhan bakteri patogen. Bakteriosin dapat diproduksi oleh kelompok Bakteri Asam Laktat (BAL), beberapa galur Bakteri Asam Laktat (BAL) dapat menghasilkan senyawa protein yang disebut bakteriosin, dan bersifat bakterisidal terhadap bakteri gram positif dan gram negatif (Tahara et al. 1996). Bakteriosin dapat diproduksi oleh Lactococcus, Lactobacillus dan Pediococcus yang berasal dari berbagai bahan makanan, misalnya nisin diproduksi oleh Lactococcus lactis, pediosin AcH dihasilkan Pediococcus acidilactic.

Terdapat beberapa bakteri patogen yang dapat ditemukan pada daging mentah. Bakteri patogen yang banyak dijumpai pada daging mentah antara lain Escherichia coli, Salmonella sp., dan Listeria monocytogenes (Usmiati dan Marwati 2007). Bakteri patogen ini akan menyebabkan daging mentah mudah mengalami pembusukan. Bakteriosin sebagai bahan pengawet alami memiliki potensi untuk mencegah berkembangnya bakteri patogen daging mentah. Penggunaan bakteriosin pada daging mentah belum terkenal di kalangan masyarakat, padahal Indonesia merupakan negara yang memiliki koleksi bakteri asam laktat. Penggunaan bakteriosin pada daging komersil di pasar belum terkenal, khususnya penggunaan pada potongan daging ayam.

Daging ayam merupakan salah satu sumber protein hewani yang dikonsumsi oleh masyarakat Indonesia. Konsumsi daging ayam sebaiknya dengan mempertimbangkan aspek kesehatan dan juga keamanan pangan. Kerusakan daging ayam oleh mikroba mengakibatkan penurunan mutu daging ayam. Jumlah dan jenis mikroba yang mencemari permukaan daging ayam ditentukan oleh penanganan sebelum penyembelihan ternak dan tingkat pengendalian higienis dan sistem sanitasi yang baik selama penanganan hingga dikonsumsi. Penggunaan bakteriosin untuk pengawet alami perlu mempertimbangkan pula sifat-sifat kestabilan bakteriosin tersebut, karena dalam pengolahan makanan sering melibatkan proses suhu baik tinggi maupun suhu rendah. Mengingat besarnya manfaat bakteriosin untuk keamanan pangan, maka perlu adanya penelitian tentang produksi bakteriosin oleh BAL Lactobacillus plantarum serta aplikasinya untuk pengawetan daging ayam broiler. Penelitian ini bertujuan mengevaluasi efektivitas plantarisin IIA-1A5 sebagai pengawet terhadap kualitas sifat fisik dan mikrobiologi daging ayam bagian paha selama penyimpanan suhu refrigerator.

\section{METODE}

Penelitian terdiri dari 2 tahap, yaitu: (1) purifikasi plantarisin; (2) penggunaan plantarisin IIA-1A5 pada daging ayam bagian paha.

\section{Purifikasi Parsial Menggunakan Amonium Sulfat (Modifikasi Hata et al. 2010)}

Media MRSB sebanyak $1000 \mathrm{~mL}$ ditambahkan yeast extract 3\% yang telah diinokulasi dengan $10 \%$ kultur L. plantarum IIA-1A5, diinkubasi, dan disimpan pada refrigerator selanjutnya disentrifugasi. Sentrifugasi dilakukan dengan kecepatan $10000 \mathrm{rpm}$ selama 20 menit pada suhu $4{ }^{\circ} \mathrm{C}$ untuk mendapatkan supernatan bebas sel (SBS). SBS disaring menggunakan membran saring Minisart diameter $0.20 \mu \mathrm{m}$, demikian juga $\mathrm{NaOH} 1 \mathrm{~N}$ yang digunakan untuk menetralkan pH SBS yaitu antara 6-7.

Seluruh tahapan ini dilakukan pada suhu refrigerator. SBS selanjutnya dievaporasi dengan menggunakan Heidolph VV micro evaporator sampai volumenya menjadi setengah dari volume awal pada suhu refrigerator. Masingmasing ulangan supernatan ditambah serbuk amonium sulfat sambil dihomogenkan perlahan-lahan sampai penjenuhan $90 \%$ pada suhu refrigerator. Proses penjenuhan dilakukan secara bertahap mulai dari $20 \%, 40 \%, 60 \%, 80 \%$, dan $90 \%$ untuk mendapatkan endapan protein (presipitat bakteriosin). Presipitat kemudian dikoleksi pada labu erlenmeyer yang sudah disterilkan.

\section{Dialisis (Hata et al. 2010)}

Dialisis dilakukan terhadap presipitat bakteriosin yang telah dikoleksi dari tahapan sebelumnya didialisis dengan menggunakan membran dialisis berdiameter $20 \mathrm{kDa}$ (Waco, Jepang) dan bufer potassium phosphate. Tahapan dialisis dilakukan selama 12 jam untuk menghilangkan amonium sulfat yang bercampur dengan endapan protein plantarisin. Bufer perlu diganti secara berkala agar tidak keruh.

Bufer diganti sebanyak 3 kali yaitu pada jam kedua, keempat, dan keenam. Proses dialisis ini dilakukan pada suhu refrigerator $\left(4{ }^{\circ} \mathrm{C}\right)$. Hasil yang didapat dari proses dialisis adalah ekstrak kasar bakteriosin dari L. plantarum (plantarisin). Plantarisin kasar hasil dialisis digunakan sebagai bahan pengawet pada penelitian.

\section{Analisis Kadar Protein Metode Lowry (Lowry et al. 1951)}

Penetapan kadar protein metode Lowry et al. (1951) sebagai berikut: $1 \mathrm{~mL}$ suspensi protein dimasukkan ke dalam tabung reaksi dan ditambah $1 \mathrm{~mL}$ larutan $\mathrm{Na} 2 \mathrm{CO} 32 \%$ (w/v) dalam $\mathrm{NaOH} 0.1 \mathrm{~N}, \mathrm{Na}+\mathrm{K}+$ tartrate $1 \%(\mathrm{w} / \mathrm{v})$, dan $\mathrm{CuSO} 4$ $0.5 \%(\mathrm{w} / \mathrm{v})$ dengan perbandingan 10:0.5:0.5. Sebanyak 3 $\mathrm{mL}$ Folin-ciocalteu ditambahkan ke dalam tabung reaksi. Setelah diinkubasi selama 10 menit, absorban dibaca pada A $650 \mathrm{~nm}$. Untuk kurva standar, digunakan BSA dengan konsentrasi $0 ; 0.1 ; 0.2 ; 0.3 ; 0.4$, dan $0.5 \mathrm{mg} \mathrm{mL}$ -

\section{Uji Aktivitas Antimikroba}

Aktivitas antibakteri berdasarkan metode modifikasi dari Dhiman et al. (2011), bahwa untuk menentukan aktivitas antibakteri plantarisin, $0.1 \mathrm{~mL}$ bakteri patogen dituangkan dengan media Muller Hinton Agar $(20 \mathrm{~mL})$ di cawan petri $(90 \mathrm{~mm})$. Disterilkan paper disc (Oxoid, United Kingdom) direndam dalam eppendorf yang berbeda dan berisi plantarisin IIA-1A5 sebanyak $50 \mu \mathrm{L}$ dari konsentrasi 
yang berbeda. Cawan yang telah selesai mendapat perlakuan selanjutnya dilakukan proses inkubasi,

Cawan diinkubasi pada $37^{\circ} \mathrm{C}$ selama 24 jam untuk Salmonella typhimurium ATCC 14028 dan Escherichia coli ATCC 25922. Proses inkubasi dilakukan dalam inkubator sehingga suhunya terkontrol. Setelah inkubasi, aktivitas antimikroba plantarisin ditentukan oleh pembentukan zona bening di sekitar paper disc. Zona bening diukur diameternya untuk mengetahui zona hambat plantarisin.

\section{Penggunaan Plantarisin IIA-1A5 pada Daging Ayam Bagian Paha}

Daging ayam bagian paha diperoleh dari Rumah Potong Ayam Cangkurawok-Bogor. Sebanyak 6 potong paha ayam yang telah dipotong pada tempat dan menggunakan alat steril diletakkan masing-masing pada 2 wadah steril. Untuk daging dengan perlakuan plantarisin, ditimbang 3 potong paha ayam, kemudian sebanyak 10\% larutan plantarisin dari bobot paha ayam dibuat dari aquadest steril dan plantarisin kasar dengan konsentrasi 6.25 per $100 \mathrm{~mL}$ aquadest.

Plantarisin disemprotkan pada seluruh bagian daging secara merata sampai cairan habis dan ditunggu 30 menit agar plantarisin meresap ke daging. Hal ini dilakukan di dalam laminar air flow agar tetap steril. Daging perlakuan dan daging kontrol selanjutnya dimasukkan pada 6 plastik steril disimpan pada suhu refrigerator untuk dianalisa pada hari ke-0, 2, 4, 6, 8, dan 10 .

\section{Analisis Fisik}

Analisis fisik dilakukan dengan mengetahui $\mathrm{pH}$ daging menggunakan $\mathrm{pH}$ meter (Hanna Instrument, USA), serta mengetahui $\mathrm{a}_{\mathrm{w}}$ daging menggunakan $\mathrm{a}_{\mathrm{w}}$ meter SAL-T $\&$ Sensor-Check SC Number 75. Pengukuran $\mathrm{a}_{\mathrm{w}}$ dan $\mathrm{pH}$ daging dilakukan pada sampel daging pada hari ke-0, 2, 4, 6,8 , dan 10 pada penyimpanan suhu refrigerator.

Pengukuran $\mathrm{pH}$ menggunakan $\mathrm{pH}$ meter yang dikalibrasi dengan larutan buffer $\mathrm{pH} 4$ dan 7 sebelum digunakan. Elektroda yang telah dibilas dengan air akuades ditusukkan ke dalam sampel sampai ujung elektroda tertutup sampel. Hasil pengukuran Nilai $\mathrm{pH}$ yang dibaca adalah nilai saat nilai pada $\mathrm{pH}$ meter telah stabil (AOAC 2005).

Pengukuran $\mathrm{a}_{\mathrm{w}}$ diawali dengan kalibrasi alat dengan memasukkan garam ke dalam wadah yang telah tersedia. Jenis garam yang digunakan adalah $\mathrm{BaCl}_{2}, \mathrm{Mg}\left(\mathrm{NO}_{3}\right)_{2}$, $\mathrm{NaCl}$, dan $\mathrm{KCl}$. Sebanyak $5 \mathrm{~g}$ sampel daging dihaluskan lalu dimasukkan ke dalam alat $\mathrm{a}_{\mathrm{w}}$ meter. Tunggu sampai layar $\mathrm{a}_{\mathrm{w}}$ meter menunjukkan waktu 80 detik setelah sampel dimasukkan. Nilai $\mathrm{a}_{\mathrm{w}}$ dicatat setelah sampel dimasukkan ke dalam alat selama 80 detik (AOAC 2005).

\section{Analisis Kadar Air}

Pengukuran kadar air (AOAC 2005) Sampel daging yang telah dihaluskan ditimbang sebanyak $2 \mathrm{~g}$ dalam wadah yang bobot wadahnya telah diketahui dengan menggunakan timbangan analitik. Wadah dan isinya dipanaskan dalam oven dengan suhu $105^{\circ} \mathrm{C}$ hingga diperoleh bobot yang tidak berubah lagi. Kadar air dihitung dengan rumus sebagai berikut:

\section{Analisis Mikrobiologi}

Berdasarkan jam pengamatan, baik daging kontrol maupun daging dengan perlakuan plantarisin, sebanyak 25 $\mathrm{g}$ daging dipotong halus ditambah dengan Buffered Peptone Water (BPW) $225 \mathrm{~mL}$. Analisis mikrobiologi dilakukan dengan pour plate method. Alat yang digunakan selama proses analisis selalu dalam keadaan steril.

Media yang digunakan adalah plate count agar (PCA) untuk total plate count (TPC), Metode total plate count (TPC) jumlah pengenceran yang digunakan adalah 104, 105, 106. Pengenceran ditingkatkan jika pada pengenceran tertinggi sudah terlalu banyak untuk dihitung. Sampel diinkubasi selama 48 jam pada suhu $37^{\circ} \mathrm{C}$ (AOAC 2005).

\section{Pengujian Mutu Organoleptik}

Pengujian mutu organoleptik (Lawless dan Heymann 2010) dilakukan untuk menilai daya terima dan kualitas produk pangan dengan metode rating test menggunakan 4 interval nilai. Parameter yang dinilai meliputi warna (putih gelap, putih pucat, putih kekuningan, putih kekuningan cerah. Intensitas aroma daging ayam meliputi (sangat anyir, anyir, tidak anyir, dan aroma daging segar). Intensitas lendir (sangat berlendir, berlendir, agak berlendir, dan tidak berlendir).

Uji mutu organoleptik untuk setiap kombinasi perlakuan dilakukan dalam waktu yang sama. Pengujian mutu organoleptik dilakukan terhadap 40 orang panelis semi terlatih. Berdasarkan pengujian mutu hedonik organoleptik ini diketahui perlakuan yang terbaik yaitu dengan nilai terbesar.

\section{Analisis Data}

Data penelitian dikoleksi dan kemudian dianalisis menggunakan analisis ragam atau Analysis of Variance (ANOVA) dengan 2 perlakuan dan 3 ulangan berdasarkan rancangan acak lengkap faktorial. Dilanjutkan dengan banding berganda Duncan Multiple Rank Test (DMRT) jika hasil analisis ragam berbeda (Steel dan Torrie 1995). Model linear yang digunakan sebagai berikut:

Kadar air $=\underline{\text { Selisih bobot total sebelum dengan setelah pengovenan }} \times 100$ Bobot total sebelum pengovenan

\section{Keterangan}

$\mathrm{Y}_{\mathrm{ijk}} \quad$ : Nilai rata-rata hasil pengamatan respon perlakuan penambahan plantarisin asal L. plantarum IIA-1A5 ke-i dan lama penyimpanan ke-j $(0,2,4,6,8$, dan 10) hari pada ulangan ke $\mathrm{k}(1,2$, dan 3$)$;

$\mu \quad$ : Nilai rata-rata pengamatan kualitas daging ayam bagian paha;

ai : Pengaruh perlakuan penambahan plantarisin asal L. plantarum IIA-1A5 ke-i terhadap kualitas daging ayam bagian paha;

$\beta \mathrm{j} \quad$ : Pengaruh lama penyimpanan ke-j $(0,2,4,6,8$, dan 10) hari terhadap kualitas daging ayam bagian paha;

$(\alpha \beta)$ ij : Pengaruh interaksi antara perlakuan penambahan plantarisin asal L. plantarum IIA-1A5 ke-i dengan lama penyimpanan ke-j $(0,2,4,6,8$, dan 10) hari terhadap kualitas daging ayam bagian paha;

cijk : Pengaruh galat percobaan dari perlakuan perlakuan 
penambahan plantarisin asal L. plantarum IIA-1A5 ke-i dan lama penyimpanan ke-j $(0,2,4,6,8$, dan 10) hari pada ulangan ke $\mathrm{k}(1,2$, dan 3$)$.

\section{HASIL DAN PEMBAHASAN}

\section{Purifikasi Parsial Plantarisin IIA-1A5}

Proses purifikasi plantarisin untuk menghasilkan plantarisin kasar meliputi dua tahap, yaitu purifikasi parsial menggunakan amonium sulfat dan dialisis. Purifikasi parsial dengan menggunakan amonium sulfat 90\% dilakukan untuk mengendapkan protein sehingga dapat terpisah dari substansi lain yang terkandung dalam SBS dan diperoleh presipitat plantarisin. Keuntungan menggunakan garam amonium sulfat antara lain karena mempunyai kelarutan tinggi, relatif lebih murah, non toksik, $\mathrm{pH}$ moderat, dan tidak mempengaruhi enzim (Tokuyasu et al. 1996).

Proses sentrifugasi dilakukan untuk membuang selsel bakteri Lactobacillus plantarum IIA-1A5 dari kultur cair Lactobacillus plantarum IIA-1A5 sehingga didapat supernatan bebas sel (SBS). Nilai pH SBS yang diukur dari hasil sentrifugasi masih dalam keadaan $\mathrm{pH}$ asam yaitu sekitar 4.08, penetralan dilakukan dengan $\mathrm{NaOH} 1 \mathrm{~N}$ sehingga $\mathrm{pH}$ akhir berada pada kisaran pH 5.8-6.2. Hal ini bertujuan untuk menetralisir asam laktat dan hidrogen peroksida yang juga dihasilkan oleh Lactobacillus plantarum IIA-1A5, karena pada kondisi tersebut aktivitas bakteriosin yang terkandung dalam SBS dapat optimal. Berdasarkan Hata et al. (2010), aktivitas antimikroba yang optimal 90\%-100\% dari plantarisin PASM1 asal Lactobacillus plantarum A-1 ditunjukan pada kisaran $\mathrm{pH} 5.5$ hingga $\mathrm{pH}$ 7. Produksi bakteriosin terjadi pada fase pertumbuhan eksponensial dan berakhir ketika memasuki fase stasioner. Proses dialisis secara difusi dilakukan untuk menghilangkan (menurunkan) konsentrasi garam amonium sulfat yang masih terkandung dalam presipitat plantarisin IIA-1A5 sehingga diperoleh plantarisin kasar.

Plantarisin IIA-1A5 yang diperoleh setelah proses dialisis kemudian dilakukan uji tantang. Pengujian dilakukan untuk mengetahui diameter zona hambat pada bakteri gram positif dan bakteri gram negatif. Berdasarkan hasil pengukuran diameter zona hambat plantarisin IIA-1A5 terhadap bakteri patogen aktivitas antimikroba plantarisin seperti yang tertera pada Tabel 1. Menurut FAO dan WHO (2009) Jenis bakteri yang biasanya mengkontaminasi daging ayam adalah Salmonella, sehingga diperlukan upaya pencegahan pertumbuhan Salmonella pada daging ayam.

Persentase plantarisin berpengaruh nyata terhadap zona hambat pertumbuhan bakteri $(\mathrm{P}<0.05)$. Tabel 1 menunjukkan bahwa plantarisin IIA-1A5 efektif dalam menghambat pertumbuhan bakteri $E$. coli sehingga terbentuk zona hambat bakteri. Bakteriosin dapat merusak dinding sel bakteri, sehingga menyebabkan kematian E. coli (Hata et al. 2010). Semakin tinggi persentase plantarisin, zona hambat yang dihasilkan semakin besar. Hal ini menunjukkan semakin banyak bakteri $E$. coli yang dihambat oleh aktivitas plantarisin. Zona hambat tertinggi terdapat pada persentase platarisin tertinggi yaitu $50 \%$.
Tabel 1. Diameter zona hambat plantarisin IIA-1A5 terhadap bakteri patogen $(\mathrm{mm})$

\begin{tabular}{llll}
\hline $\begin{array}{c}\text { Persentase } \\
\begin{array}{c}\text { Plantarisin } \\
(\%)\end{array}\end{array}$ & $\begin{array}{c}\text { Persentase } \\
\text { Protein } \\
\left(\mu \mathrm{g} \mathrm{mL}^{-1}\right)\end{array}$ & $\begin{array}{c}\text { Escherichia coli } \\
\text { ATCC 25922 }\end{array}$ & $\begin{array}{c}\text { Salmonella } \\
\text { typhimurium } \\
\text { ATCC } 14028\end{array}$ \\
\hline 50 & 170.68 & $10.86 \pm 0.30 \mathrm{a}$ & $11.59 \pm 0.12 \mathrm{a}$ \\
25 & 85.34 & $10.41 \pm 0.30 \mathrm{ab}$ & $10.17 \pm 0.37 \mathrm{~b}$ \\
12.5 & 42.67 & $10.04 \pm 0.21 \mathrm{abc}$ & $9.77 \pm 0.16 \mathrm{~b}$ \\
6.25 & 21.33 & $9.43 \pm 0.27 \mathrm{bcd}$ & $8.55 \pm 0.06 \mathrm{c}$ \\
3.13 & 10.67 & $9.16 \pm 0.44 \mathrm{~cd}$ & $8.39 \pm 0.06 \mathrm{c}$ \\
1.56 & 5.33 & $8.94 \pm 0.05 \mathrm{~d}$ & $8.44 \pm 0.05 \mathrm{c}$ \\
\hline
\end{tabular}

Keterangan: Rata-rata \pm sd, angka disertai huruf berbeda pada kolom yang sama menunjukkan perbedaan yang signifikan pada taraf $5 \%$

Zona hambat plantarisin terhadap Salmonella memiliki zona hambat yang tidak jauh berbeda dengan E. coli. Semakin tinggi konsentrasi plantarisin juga akan meningkatkan zona hambat terhadap bakteri. Pembentukan zona hambat ini akibat adanya aktivitas antimikroba. Hal ini sesuai pendapat Jawetz et al. (2005), bahwa aktivitas antimikroba pada antibiotik gentamicin dan klorampenicol dapat menghambat sintesis protein pada bakteri, sedangkan ampicilin dapat menghambat sintesis dinding sel bakteri sehingga aktif melawan pertumbuhan bakteri. Pada persentase plantarisin yang diamati, zona hambat plataricin termasuk rendah jika dibandingkan dengan klorampenicol. Zona hambat klorampenicol termasuk rendah pada diameter $<12 \mathrm{~mm}$ (CLSI 2016).

Berdasarkan hasil uji tantang, plantarisin berpotensi digunakan sebagai pengawet bahan pangan sebab memiliki kemampuan menghambat bakteri patogen seperti E. coli dan Salmonella sp. Hal ini sesuai Gong et al. (2010), plantarisin MG terdapat aktivitas antimikroba terhadap bakteri gram positif dan gram negatif termasuk L. monocytogenes, S. aureus, S. typhimurium, dan E. coli. Penurunan aktivitas bakteri patogen dalam bahan pangan akan menurunkan potensi pembusukan makanan, sehingga masa simpan bahan pangan dapat meningkat.

\section{Penggunaan Plantarisin IIA-1A5 pada Daging Ayam Bagian Paha}

Analisis kualitas fisik daging ayam dilakukan untuk mengetahui pengaruh pemberian plantarisin terhadap nilai $\mathrm{pH}$, aktivitas air (water activity), dan kadar air (Tabel 2). Hasil pengukuran $\mathrm{pH}$ menunjukkan hasil bahwa $\mathrm{pH}$ daging ayam tanpa plantarisin (kontrol) dan daging disemprot plantarisin berada pada kondisi di atas $\mathrm{pH}$ normal daging ayam broiler. Menurut Laack et al. (2000) nilai pH normal daging ayam broiler berkisar antara 5.96 sampai 6.07.

Menurut Soeparno (2005), nilai $\mathrm{pH}$ daging yang lebih rendah atau terjadi penurunan nilai $\mathrm{pH}$ pada daging disebabkan oleh penguraian glikogen otot oleh enzimenzim glikolisis secara anaerob menjadi asam laktat. Kondisi cadangan glikogen yang rendah sebelum ayam dipotong, mengakibatkan penguraian glikogen menjadi rendah. Penguraian glikogen yang rendah menghasilkan asam laktat pada daging lebih sedikit, sehingga penurunan 
Tabel 2 Kondisi sifat fisik daging ayam pada penyimpanan suhu refrigerator

\begin{tabular}{|c|c|c|c|}
\hline Lama & Kontrol & Plantarisin & Rataan \\
\hline \multicolumn{4}{|c|}{$\mathrm{pH}$} \\
\hline 0 & $6.47 \pm 0.04$ & $6.35 \pm 0.03$ & $6.50 \pm 0.05 p$ \\
\hline 2 & $6.46 \pm 0.04$ & $6.48 \pm 0.02$ & $6.47 \pm 0.03 \mathrm{q}$ \\
\hline 4 & $6.45 \pm 0.01$ & $6.46 \pm 0.01$ & $6.45 \pm 0.01 \mathrm{q}$ \\
\hline 6 & $6.42 \pm 0.01$ & $6.43 \pm 0.01$ & $6.43 \pm 0.01 \mathrm{r}$ \\
\hline 8 & $6.39 \pm 0.02$ & $6.40 \pm 0.01$ & $6.40 \pm 0.02 \mathrm{~s}$ \\
\hline 10 & $6.35 \pm 0.01$ & $6.37 \pm 0.02$ & $6.36 \pm 0.02 \mathrm{t}$ \\
\hline Rataan & $6.42 \pm 0.05 b$ & $6.45 \pm 0.06 \mathrm{a}$ & \\
\hline \multicolumn{4}{|c|}{ Kadar air (\%) } \\
\hline 0 & $75.60 \pm 1.18$ & $76.02 \pm 0.25$ & $75.81 \pm 0.79 p$ \\
\hline 2 & $74.34 \pm 0.68$ & $75.40 \pm 0.17$ & $74.92 \pm 0.69 \mathrm{q}$ \\
\hline 4 & $74.20 \pm 0.33$ & $75.13 \pm 0.51$ & $74.67 \pm 0.63 \mathrm{q}$ \\
\hline 6 & $74.08 \pm 0.83$ & $74.72 \pm 0.20$ & $74.40 \pm 0.64 \mathrm{qr}$ \\
\hline 8 & $73.97 \pm 0.19$ & $74.50 \pm 0.57$ & $74.24 \pm 0.48 \mathrm{qr}$ \\
\hline 10 & $73.47 \pm 0.10$ & $74.07 \pm 0.13$ & $73.77 \pm 0.35 \mathrm{r}$ \\
\hline Rataan & $74.29 \pm 0.89 b$ & $74.97 \pm 0.71 \mathrm{a}$ & \\
\hline \multicolumn{4}{|c|}{ Aktivitas air $\left(a_{w}\right)$} \\
\hline 0 & $0.84 \pm 0.01 \mathrm{abc}$ & $0.85 \pm 0.01 \mathrm{abc}$ & \\
\hline 2 & $0.86 \pm 0.01 \mathrm{ab}$ & $0.85 \pm 0.02 \mathrm{abc}$ & \\
\hline 4 & $0.85 \pm 0.01 \mathrm{abc}$ & $0.83 \pm 0.03 \mathrm{~cd}$ & \\
\hline 6 & $0.85 \pm 0.01 \mathrm{ab}$ & $0.82 \pm 0.02 \mathrm{~d}$ & \\
\hline 8 & $0.85 \pm 0.01 \mathrm{abc}$ & $0.84 \pm 0.01 \mathrm{bcd}$ & \\
\hline 10 & $0.85 \pm 0.01 \mathrm{abc}$ & $0.86 \pm 0.01 \mathrm{a}$ & \\
\hline
\end{tabular}

Keterangan : Rata-rata \pm sd, angka disertai huruf berbeda pada kolom dan baris yang sama menunjukkan perbedaan yang signifikan pada taraf $5 \%$

nilai $\mathrm{pH}$ daging juga lebih sedikit. Tabel 2 menampilkan nilai $\mathrm{pH}$ daging ayam yang berbeda selama penyimpanan $0,2,4,6,8$, dan 10 hari. Nilai $\mathrm{pH}$ daging ayam bagian paha yang berbeda juga ditunjukkan oleh perlakuan pemberian plantarisin.

Nilai pH pada Daging Ayam Bagian Paha. Berdasarkan Tabel 2, nilai $\mathrm{pH}$ daging ayam kontrol dan plantarisin memiliki perbedaan nyata $(\mathrm{P}<0.05)$. Hal ini menunjukkan bahwa daging yang diberi perlakuan plantarisin nilai $\mathrm{pH}$ akan meningkat, sebab plantarisin memiliki $\mathrm{pH}$ 6, kemudian ditambah dengan nilai $\mathrm{pH}$ aquadest yaitu 7 , sehingga nilai $\mathrm{pH}$ daging yang diberi perlakuan plantarisin akan meningkatkan $\mathrm{pH}$.

Berdasarkan lama penyimpanan, semakin lama umur simpan nilai $\mathrm{pH}$ daging ayam akan menurun. Hal ini disebabkan glikogen otot semakin teruarai menjadi asam laktat. Menurut Soeparno (1992), bahwa pH daging akan mengalami penurunan sesuai dengan waktu penyimpanan, semakin lama penyimpanan akan semakin rendah $\mathrm{pH}$ daging sampai tercapai $\mathrm{pH}$ akhir daging. Hal ini terjadi pada daging ayam penelitian yang mengalami penurunan pH selama penyimpanan.

Kadar Air pada Daging Ayam Bagian Paha. Nilai kadar air berhubungan dengan perubahan nilai $\mathrm{pH}$, pada Tabel 2 dapat dilihat nilai kadar air daging kontrol dan plantarisin selama penyimpanan. Penurunan nilai $\mathrm{pH}$ akan mempengaruhi komponen sifat fisik daging yang lain. Laju penurunan $\mathrm{pH}$ otot yang cepat akan mengakibatkan rendahnya kapasitas mengikat air, karena meningkatnya kontraksi aktin dan miosin yang terbentuk, dengan demikian akan memeras cairan keluar dari dalam daging (Afrianti et al. 2013). Suhu tinggi juga dapat mempercepat penurunan $\mathrm{pH}$ otot pascamortem dan menurunkan kapasitas mengikat air karena meningkatnya denaturasi protein otot dan meningkatnya perpindahan air ke ruang ekstraseluler (Lawrie 1996). Hal ini sesuai dengan penelitian, bahwa kadar air daging ayam broiler bagian paha mengalami penurunan persentase kadar air selama penyimpanan baik kontrol maupun perlakuan plantarisin.

Penurunan kadar air pada daging ayam broiler bagian paha selama penyimpanan diduga akibat penurunan nilai $\mathrm{pH}$ daging ayam bagian paha yang terjadi secara beriringan. Semakin banyak air yang keluar dari daging, maka kadar air dalam daging menjadi berkurang dan mempengaruhi ketersediaan air bebas dalam daging. Rataan nilai kadar air daging ayam yang disemprot plantarisin lebih tinggi dibanding dengan kontrol, hal ini disebabkan karena daging yang disemprot plantarisin menyerap cairan dari perlakuan plantarisin. 
Cairan sebanyak $10 \%$ dari bobot daging ini akan meningkatkan kadar air daging, sehingga rataan nilai kadar air pada daging paha ayam yang diberi perlakuan plantarisin lebih tinggi dibanding kontrol. Nilai kadar air daging ayam bagian paha baik kontrol maupun perlakuan masih dalam kondisi normal. Hal ini sesuai dengan pendapat Forest et al. (1975) bahwa kadar air daging ayam broiler yaitu sebesar 65\%-80\%.

Nilai Aktivitas Air pada Daging Ayam Bagian Paha. Tabel 2 menunjukkan bahwa interaksi antara lama simpan dengan perlakuan plantarisin berpengaruh nyata $(\mathrm{P}<0.05)$ terhadap aktivitas air $\left(\mathrm{a}_{\mathrm{w}}\right)$. Berdasarkan Pengamatan, daging disemprot plantarisin cenderung mengalami penurunan pada hari keempat dan hari keenam. Hal ini sesuai dengan literatur yang menyatakan pemberian bahan pengawet cenderung dapat menurunkan aktivitas air (Arief et al. 2012).

Sebenarnya, penurunan $a_{w}$ merupakan kondisi yang sesuai untuk menghambat pertumbuhan bakteri pada pangan. Penurunan aktivitas air pada pangan dilakukan dengan cara menambahkan padatan, ion, koloid hidrofilik, pembekuan, dan pengeringan.

Nilai Mikrobiologi Daging Ayam Bagian Paha. Pengaruh interaksi kualitas mikrobiologi daging ayam bagian paha antara penyemprotan plantarisin dan lama simpan terhadap total mikroba daging ayam bagian paha pada suhu refrigerator berbeda nyata $(\mathrm{P}<0.05)$. Perbedaan tiap perlakuan dapat dilihat pada Tabel 3 .

Tabel 3. Kondisi sifat mikrobiologi total mikroba pada daging ayam bagian paha

\begin{tabular}{ccc}
\hline $\begin{array}{c}\text { Lama } \\
\text { Penyimpanan }\end{array}$ & Kontrol & Plantarisin \\
\hline & \multicolumn{2}{c}{ Total Mikroba $\left(\log \mathrm{cfu} \mathrm{g}^{-1}\right)$} \\
0 & $6.24 \pm 0.01 \mathrm{~h}$ & $6.00 \pm 0.01 \mathrm{i}$ \\
2 & $7.48 \pm 0.02 \mathrm{f}$ & $6.34 \pm 0.01 \mathrm{~g}$ \\
4 & $8.23 \pm 0.04 \mathrm{e}$ & $7.44 \pm 0.01 \mathrm{f}$ \\
6 & $9.36 \pm 0.02 \mathrm{c}$ & $8.32 \pm 0.01 \mathrm{~d}$ \\
8 & $10.32 \pm 0.06 \mathrm{a}$ & $9.46 \pm 0.06 \mathrm{~b}$ \\
10 & $10.32 \pm 0.04 \mathrm{a}$ & $9.47 \pm 0.07 \mathrm{~b}$ \\
\hline
\end{tabular}

Keterangan: Rata-rata \pm sd, angka disertai huruf berbeda pada kolom dan baris yang sama menunjukkan perbedaan yang signifikan pada taraf $5 \%$

Berdasarkan ketentuan yang telah ditetapkan Badan Standardisasi Nasional (BSN) SNI 3924 (2009) persyaratan mikrobiologi dalam daging ayam broiler yang beredar di Indonesia adalah total plate count (TPC) 106 cfu g-1. Nilai TPC tersebut merupakan batasan maksimum cemaran mikroba pada daging ayam, sehingga apabila melebihi jumlah batasan daging tidak layak dikonsumsi. Berdasarkan hasil penelitian, nilai TPC paha ayam sudah menunjukkan hasil yang melebihi batas SNI 3924 (2009) pada hari pertama. Hal ini karena daging ayam diperoleh dari rumah potong ayam (RPA) tradisional. RPA tradisional memiliki sanitasi yang kurang baik. Lokasi pemotongan dan pemisahan organ dalam ayam terletak dalam 1 ruangan tanpa sekat atau pemisah.

Berdasarkan hasil penelitian, lama penyimpanan menunjukkan pengaruh terhadap nilai total mikroba daging ayam bagian paha. Semakin lama penyimpanan, nilai total mikroba akan terus meningkat, tetapi peningkatan total mikroba pada daging yang diberi perlakuan plantarisin lebih rendah dibanding kontrol. Hal ini menunjukkan plantarisin memiliki aktivitas menghambat pertumbuhan bakteri.

Pengujian organoleptik atau uji sensori dilakukan untuk mengetahui pengaruh pemberian plantarisin terhadap warna, aroma, dan banyaknya lendir pada daging ayam broiler bagian paha selama penyimpanan (Tabel 4). Warna daging merupakan salah satu parameter spesifik dalam menentukan kualitas daging. Konsumen akan memilih suatu produk makanan sesuai selera dan dilihat secara visual. Lendir diduga sebagai salah satu akibat dari kebusukan daging ayam, sehingga dilakukan pengujian organoleptik terhadap banyaknya lendir pada daging ayam bagian paha.

Hasil pengujian menunjukkan masing-masing atribut sensoris berbeda nyata $(\mathrm{P}<0.05)$. Warna terdiri dari 1) putih gelap; 2) putih pucat; 3) putih kekuningan; 4) putih kekuningan cerah. Aroma daging terdiri dari 1) sangat anyir; 2) anyir; 3) agak anyir; 4) aroma daging segar. Banyaknya lendir terdiri dari 1) sangat berlendir; 2) berlendir; 3) agak berlendir; 4) tidak berlendir. Konsentrasi mioglobin akan menyebabkan macam otot merah atau otot putih (Soeparno et al. 2001). Hasil pengujian oleh panelis terhadap mutu hedonik warna, aroma, dan banyaknya lendir ditampilkan pada Tabel 4.

Berdasarkan penampilan fisik, warna daging ayam segar adalah putih kekuning-kuningan (Yulistiani 2010). Pakan, spesies, bangsa, umur, jenis kelamin, stres (tingkat aktivitas dan tipe otot), oksigen termasuk faktor yang mempengaruhi warna daging (Soeparno 2005). Berdasarkan Tabel 4 daging ayam bagian paha mengalami perubahan warna selama penyimpanan dari warna putih kekuningan cerah sampai putih gelap baik pada daging kontrol maupun perlakuan. Hal ini berhubungan dengan nilai $\mathrm{pH}$ daging yang berada pada selang 6.35-6.53. Menurut Cassens (1966) Perubahan pH akhir antara 6.0-6.5 mengakibatkan perubahan warna daging menjadi lebih gelap. Hal ini sesuai dengan pendapat Fletcher (1999) nilai $\mathrm{pH}$ merupakan faktor yang mempengaruhi warna daging.

Berdasarkan Tabel 4, aroma daging mengalami perubahan dari aroma daging segar sampai aroma sangat anyir. Semakin lama penyimpanan aroma daging berubah secara berurutan dari aroma daging segar menjadi beraroma agak anyir, anyir, dan sampai hari kesepuluh menjadi sangat anyir. Hal tersebut sesuai dengan pendapat Forrest et al. (1975) bahwa beberapa faktor yang mempengaruhi aroma daging yaitu lama waktu dan kondisi penyimpanan daging setelah pemotongan.

Perubahan jumlah lendir pada daging ayam terjadi selama penyimpanan di suhu refrigerator. Selama penyimpanan, jumlah lendir meningkat dari tidak berlendir, menjadi agar berlendir, berlendir, dan terakhir sangat berlendir. Berdasarkan hasil pengujian organoleptik, respon lendir tertinggi berada pada daging ayam bagian 
Tabel 4 Hasil uji organoleptik daging ayam dengan perlakuan plantarisin

\begin{tabular}{|c|c|c|}
\hline Lama & Kontrol & Plantarisin \\
\hline \multicolumn{3}{|c|}{ Warna } \\
\hline 0 & $3.53 \pm 0.64 \mathrm{e}$ & $3.63 \pm 0.54 \mathrm{e}$ \\
\hline 2 & $2.80 \pm 0.65 \mathrm{c}$ & $2.95 \pm 0.71 \mathrm{~d}$ \\
\hline 4 & $2.65 \pm 0.92 \mathrm{c}$ & $2.95 \pm 0.81 \mathrm{~d}$ \\
\hline 6 & $2.23 \pm 1.35 \mathrm{~b}$ & $2.20 \pm 1.24 \mathrm{~b}$ \\
\hline 8 & $2.03 \pm 0.92 \mathrm{ab}$ & $2.08 \pm 0.76 \mathrm{ab}$ \\
\hline 10 & $1.30 \pm 0.61 \mathrm{a}$ & $1.43 \pm 0.68 \mathrm{a}$ \\
\hline \multicolumn{3}{|c|}{ Aroma } \\
\hline 0 & $3.68 \pm 0.53 \mathrm{f}$ & $3.68 \pm 0.53 \mathrm{f}$ \\
\hline 2 & $3.15 \pm 0.80 \mathrm{e}$ & $3.18 \pm 0.55 \mathrm{e}$ \\
\hline 4 & $2.48 \pm 0.99 \mathrm{c}$ & $2.73 \pm 0.93 \mathrm{~d}$ \\
\hline 6 & $2.03 \pm 0.86 \mathrm{ab}$ & $2.35 \pm 0.95 \mathrm{c}$ \\
\hline 8 & $1.78 \pm 0.73 \mathrm{ab}$ & $2.10 \pm 0.81 b$ \\
\hline 10 & $1.25 \pm 0.49 \mathrm{a}$ & $1.28 \pm 0.51 \mathrm{a}$ \\
\hline \multicolumn{3}{|c|}{ Lendir } \\
\hline 0 & $3.63 \pm 0.70 \mathrm{f}$ & $3.70 \pm 0.52 \mathrm{~g}$ \\
\hline 2 & $3.28 \pm 0.72 \mathrm{e}$ & $3.30 \pm 0.52 \mathrm{e}$ \\
\hline 4 & $2.90 \pm 0.78 \mathrm{c}$ & $2.98 \pm 0.62 \mathrm{c}$ \\
\hline 6 & $2.85 \pm 0.92 \mathrm{c}$ & $2.90 \pm 0.81 \mathrm{c}$ \\
\hline 8 & $2.05 \pm 0.64 \mathrm{ab}$ & $2.40 \pm 0.74 b$ \\
\hline 10 & $1.43 \pm 0.55 \mathrm{a}$ & $1.48 \pm 0.60 \mathrm{a}$ \\
\hline
\end{tabular}

Keterangan: Rata-rata $\pm \mathrm{sd}$, angka dengan huruf berbeda pada kolom dan baris yang sama menunjukkan perbedaan yang signifikan pada taraf 5\%. Warna terdiri dari 1) putih gelap; 2) putih pucat; 3) putih kekuningan; 4) putih kekuningan cerah. Aroma daging terdiri dari 1) sangat anyir; 2) anyir; 3) agak anyir; 4) aroma daging segar. Banyaknya lendir terdiri dari 1) sangat berlendir; 2) berlendir; 3) agak berlendir; 4) tidak berlendir.

paha setelah disimpan selama 10 hari. Lendir terjadi akibat penurunan $\mathrm{pH}$ yang mengakibatkan cairan keluar. Lendir memiliki hubungan dengan cairan yang keluar dari daging selama penyimpanan. Hal tersebut sesuai dengan pendapat Afrianti et al. (2013) bahwa laju penurunan pH otot yang cepat akan mengakibatkan rendahnya kapasitas mengikat air, karena meningkatnya kontraksi aktin dan miosin yang terbentuk, dengan demikian akan memeras cairan keluar dari dalam daging.

\section{KESIMPULAN}

Interaksi antara pemberian plantarisin IIA-1A5 dan waktu simpan daging ayam bagian paha berpengaruh nyata terhadap kualitas daging paha ayam. Plantarisin IIA-1A5 efektif menghambat pertumbuhan bakteri gram positif dan bakteri gram negatif sehingga total mikroba daging paha ayam yang diberi perlakuan plantarisin lebih rendah dari daging paha ayam kontrol selama penyimpanan. Plantarisin IIA-1A5 memiliki potensi sebagai pengawet daging ayam bagian paha. Secara umum, berdasarkan uji fisik, kadar air, mikrobiologi, dan organoleptik terhadap daging paha ayam menunjukkan bahwa daging paha ayam yang diberi plantarisin memiliki kualitas yang lebih baik dibandingkan dengan daging paha ayam tanpa plantarisin.

\section{DAFTAR PUSTAKA}

Afrianti M, Dwiloka B, Setiani BE. 2013. An effect of soaking senduduk (Melastoma malabathricum L.) leaf extract for bacteria total, $\mathrm{pH}$, and water content in broiler meat with during storage. Jurnal Pangan dan Gizi 04(7): 49-56.

Ammor S, Tauveron G, Dufour E, Chevallier I. 2006. Antibacterial activity of lactic acid bacteria against spoilage and pathogenic bacteria isolated from the same meat smallscalefascility:1 Screening and characterization of the antibacterial compounds. Journal Food Control 17:454-461.

AOAC [Association Official Analitycal Chemistry]. 2005. Official Method of Analysis. Ed ke-18. Maryland (USA): AOAC Inc.

Arief II, Jenie BSL, Suryati T, Ayuningtyas G, Fuziawan A. 2012. Antimicrobial activity of bacteriocin from indigenous Lactobacillus plantarum $2 \mathrm{c} 12$ and its aplication on beef meatball as biopreservative. Jurnal Indonesian Trop Anim Agric. 37(2): 90-96.

Badan Standarisasi Nasional [BSN]. 2009. Standar Nasional Indonesia (SNI) 3924:2009. Mutu Karkas dan Daging Ayam. Jakarta (ID): Badan Standarisasi Nasional.

Cassens RG. 1966. General aspect of postmortem changes. In Eskin NAM. 1990. Biochemistry of 
Foods. Ed ke-2. The University of Manitoba. Canada (US): Departement of Foods and Nutrition.

CLSI [Clinical and Laboratory Standards Institute]. 2016. Performance Standards for Antimicrobial Susceptibility Testing. Pennsylvania (USA): CLSI.

Dhiman A, Nanda A, Ahmad S, Narasimhan B. 2011. In vitro antimicrobial activity of methanolic leaf extract of psidium guajava L. J Pharm Bioallied Sci. 3(2): 226-9.

FAO, WHO. 2009. Salmonella and campylobacter in chicken meat. Microbial Assessment Series 19:1-69

Fletcher DL. 1999. Broiler breast meat color variation, $\mathrm{pH}$, and texture. Poult Sci. 78: 1323-1327.

Forrest, Aberle EB, Hendrick HB, Judge MD, Merkel RA. 1975. Principle of Meat Science. San Francisco (USA): W. H. Freeman and Company.

Gong HS, Meng XC, Wang H. 2010. Plantaricin mg active against gram-negative bacteria produced by Lactobacillus plantarum klds 1.0391 isolated from "Jiaoke", a traditional fermented cream from China. Food Control 21:89-96.

Hata T, Tanaka R,Ohmomo S. 2010. Isolation and characterization of plantarisin ASM1: A new bacteriocin produced by Lactobacillus plantarum A-1. J Food Microb. 137: 94-99.

Jawetz E, Melnick JL, Adelberg EA. 2005. Medical Microbiology. Jakarta (ID): Salemba Medika.

Laack V, Liu CH, Smith MO, Loveday HD. 2000. Characteristics of pale, soft, exudative broiler breast meat. Poult Sci. 79:1057-1061.

Lawless HT, Heymann H. 2010. Sensory Evaluation of Food Principles and Practices. New York (US): Springer.
Lawrie RA. 1996. Ilmu Daging. Terjemahan Aminuddin P. Jakarta (ID) : Universitas Indonesia Pr.

Lowry OH, Rosebrough NJ, Farr AL, Randal RJ. 1951. Protein measurement with the folin phenol reagent. $J$ Biol Chem. 193:265-275.

Soeparno. 1992. Komposisi tubuh dan evaluasi daging dada sebagai pedoman penilaian kualitas produk ayam kampung jantan. Buletin Peternakan 16: 6-14.

Soeparno, Indratiningsih, Triatmojo S, Rihastuti. 2001. Dasar Teknologi Hasil Ternak. Yogyakarta (ID): UGM Pr.

Soeparno. 2005. Ilmu dan Teknologi Daging. Yogyakarta (ID): Universitas Gadjah Mada Pr.

Steel RGD, Torrie JH. 1995. Prinsip dan Prosedur Statistik. Edisi ke-2. Terjemahan B. Sumantri. Jakarta (ID): PT Gramedia.

Tahara T, Oshimura M, Umezawa C, Kanatani K. 1996. Isolation partial characterization and mode of action acidocin J1132, a two-compound bacteriocin produced by Lactobacillus acidophilus JCM 1132. Appl Environ Microbiol. 62:892-897.

Tokuyasu K, Ono H, Hayasi K, Mori Y. 1996. Purification and characterization of extracellular chitin deacetylase from Colletotricum lindemuthianum. JBiosc Biotech Biochem. 10: 1598-1603.

Usmiati S, Marwati T. 2007. Seleksi dan optimasi proses produksi bakteriosin dari Lactobacillus sp. Jurnal Pascapanen 4 (1).

Yulistiani R. 2010. Studi daging ayam bangkai :perubahan organoleptik dan pola pertumbuhan bakteri. Jurnal Teknologi Pertanian. 11(1):27-36. 